DOI: $10.1002 / c b i c .200$ ((will be filled in by the editorial staff))

Dihydroxyacetone Kinase, a Naturally Occurring Promiscuous Enzyme

\section{From Kinase to Cyclase: An Unusual Example of Catalytic Promiscuity}

\section{Modulated by Metal Switching}

Israel Sánchez-Moreno, ${ }^{[\mathrm{a}]}$ Laura Iturrate,${ }^{[\mathrm{a}]}$ Rocio Martín-Hoyos, ${ }^{[a]}$ María Luisa Jimeno, ${ }^{[b]}$ Montaña Mena, ${ }^{[\mathrm{c}]}$ Agatha Bastida, ${ }^{[\mathrm{a}]}$ and Eduardo GarcíaJunceda*[a]

Enzyme promiscuity is a concept that in the last years is earning prominence in different fields of enzymology like biocatalysis, enzyme engineering or enzyme evolution. ${ }^{[1]}$ Catalytic promiscuity is defined as the ability of an enzyme to catalyze more than one chemical transformation. ${ }^{[1 b, c]}$ Naturally occurring catalytic promiscuity provide the starting point for a Darwinian evolution of enzymes to new functions since this process must occur gradually, while maintaining organism fitness throughout. ${ }^{[2]}$ Tawfik and co-workers ${ }^{[3]}$ have provided experimental evidence for the plasticity and "evolvability"[4] of promiscuous functions. These authors propose a model by which a protein acquires a new function, without losing the original one, and gene duplication may follow the emergence of a new function, rather than initiate it. Besides the intriguing implications that this theory of divergent molecular evolution has for protein evolution, its application to promiscuous enzymes allows to design enzymes with new catalytic activities. ${ }^{[5]}$

A special case of catalytic promiscuity is the shown by metalloenzymes, where the variety of metallic ions that can be incorporated in the active site increase the range of chemical transformations that can be catalyzed by the enzyme. Thus, there are several examples showing that protein modification via the covalent attachment of ligands that incorporate metal ions or by incorporation of the catalytic metal ion alone in a suitable site for coordination, is a strategy that allows to obtain enzymes with

[a] I. Sánchez-Moreno, Dr. L. Iturrate, R. Martín-Hoyos, Dr. A. Bastida Dr. E. García-Junceda

Departamento de Química Orgánica Biológica Instituto de Química Orgánica General, CSIC

Juan de la Cierva 3, 28006 Madrid (Spain)

Fax: (+34) 915-644-853

E-mail: eduardo.junceda@iqog.csic.es

[b] Dr. M. L. Jimeno

Centro de Química Orgánica "Manuel Lora-Tamayo" CSIC

Juan de la Cierva 3, 28006 Madrid (Spain)

[c] Dr. M. Mena

Facultad de Ciencias del Medio Ambiente, UCL-M

Campus de la Real Fábrica de Armas, 45071 Toledo, (Spain)

Supporting information for this article is available on the WWW under http://www.chembiochem.org or from the author. either modified or completely new catalytic activities. ${ }^{[6]}$

In this communication we describe the promiscuous behaviour of the dihydroxyacetone (DHA) kinase from Citrobacter freundii strain CECT 4626. This ATP-dependent DHAK is able to catalyse, beside the transfer of the $\gamma$-phosphate of the ATP to $\mathrm{DHA}$, the cyclization of the FAD to yield riboflavin 4',5'-cyclic phosphate $\left(4^{\prime}, 5^{\prime}-\mathrm{cFMN}\right)$ (Scheme 1). This catalytic promiscuity is modulated by the divalent cation that forms the complex with the phosphorylated substrate.

$$
\begin{aligned}
& \mathrm{DHA}+[\mathrm{MgATP}]^{2-} \stackrel{\mathrm{DHAK}(\mathrm{EC} \cdot 2.7 .1 .29)}{\longrightarrow} \mathrm{DHAP}+\mathrm{ADP}+\mathrm{Mg}^{2+} \\
& \mathrm{FAD} \stackrel{\mathrm{DHAK}(\mathrm{EC} \cdot 4 \cdot 6 \cdot 1.15)+\mathrm{Mn}^{2+}}{\longrightarrow} 4^{\prime}, 5^{\prime}-\mathrm{CFMN}+\mathrm{AMP}
\end{aligned}
$$

Scheme 1. Natural and promiscuous reactions catalysed by the DHAK from $C$. freundii CECT 4626 . The different chemical reactions catalysed by this enzyme are indicated by the corresponding EC numbers.

Although DHAK's are widely distributed in the three biological kingdoms, only their role in the catabolism of glycerol and in methanol assimilation in microorganisms have been well characterized. ${ }^{[7]}$ In the bacteria $C$. freundii strain DSM $30040^{[8]}$ the entire dha regulon has been cloned and characterized at molecular level. ${ }^{[9]}$ The kinetic properties and mechanism of the corresponding DHAK have been described ${ }^{[10]}$ and the X-ray structure of the full-length DHAK in complex with its substrates has been elucidated. ${ }^{[11]}$ This kinase is the only one known with an all-a nucleotide-binding domain. ${ }^{[12]}$

From a biocatalytic point of view, ATP-dependent DHAK's have been given considerable attention because their feasibility for the simple and efficient obtaining of DHAP. ${ }^{[13]}$ We have reported a multi-enzyme system for one-pot $\mathrm{C}-\mathrm{C}$ bond formation catalysed by DHAP-dependent aldolases, based in the use of the recombinant DHAK from $C$. freundii CECT 4626, for in situ DHAP formation. ${ }^{[14]}$ This enzyme (GeneBank Accession No DQ473522) is a new isoform that differs in 22 aa from the enzyme of the DSM 30040 strain (see the Supporting Information).

During the progress of our own work towards the biochemical characterization of this enzyme, Cameselle and co-workers reported the molecular identity of recombinant human and rat liver purified FAD-AMP lyase (FMN cyclase) as ATP-dependent DHAK's. ${ }^{[15]}$ These authors had previously published a series of papers in which they identified and characterized this $\mathrm{Mn}^{2+}$ dependent cyclase activity as the only enzymatic source of riboflavin 4',5'-phosphate (cFMN). ${ }^{[16]}$ Human FMN cyclase displays $39.4 \%$ sequence identity with the DHAK from $C$. freundii CECT 4626. Thus, we decided to study if the DHAK displayed as well FMN cyclase activity (Scheme 2).

The time course of the reaction catalysed by DHAK in presence of FAD and $\mathrm{Mn}^{2+}$ was followed by HPLC (see the Supporting Information). Chromatograms recorded at different reaction times shown that the decrease of the FAD peak was concomitant with the apparition of a new peak which retention 
time was coincident with the previously described for the cFMN. ${ }^{[16]}$<smiles></smiles>

Scheme 2. Promiscous reaction catalysed by DHAK from $C$. freundii CECT 4626 in presence of $\mathrm{Mn}^{2+}$.

This peak was purified and its identity unequivocally assigned by NMR and ESI-MS (see the Supporting Information). Thus, we were in presence of an enzyme able to catalyse two different reactions which were modulated by the divalent ion used as cofactor.

The different kinetic parameters for both reactions and for the different substrates are summarized in Table 1. The catalytic efficiency $\left(k_{\text {cat }} / K_{\mathrm{M}}\right)$ of DHAK for the different phosphorylated substrates was of the same order of magnitude (Table 1).

Table 1. Summary of the kinetic constants of DHAK from C. freundii CECT 4626 for the natural and promiscuous activities. ${ }^{[a]}$

\begin{tabular}{|lllll|} 
Activity & Substrate & $K_{\mathrm{M}}(\mathrm{mM})$ & $k_{\text {cat }}\left(\mathrm{s}^{-1}\right)$ & $k_{\text {cat }} / K_{\mathrm{M}}\left(\mathrm{s}^{-1} / \mathrm{M}\right)$ \\
\hline Kinase & DHA & 0.0012 & 24.13 & $1.98 \times 10^{7}$ \\
Kinase & Mg-ATP & 0.35 & 24.02 & $6.9 \times 10^{4}$ \\
Kinase & Mn-ATP & 0.65 & 24.84 & $3.8 \times 10^{4}$ \\
Cyclase & Mn-FAD & 0.017 & 0.47 & $2.8 \times 10^{4}$ \\
\hline
\end{tabular}

[a] Kinetic parameters calculated at $25^{\circ} \mathrm{C}$

However, the kinase and cyclase specific activities are drastically affected by the $\mathrm{Me}^{2+}$ used as cofactor (Figure 1).

Meanwhile the kinase activity is almost independent of the $\mathrm{Me}^{2+}$, the cyclase activity increase almost 50 times when the cofactor used was $\mathrm{Mn}^{2+}$

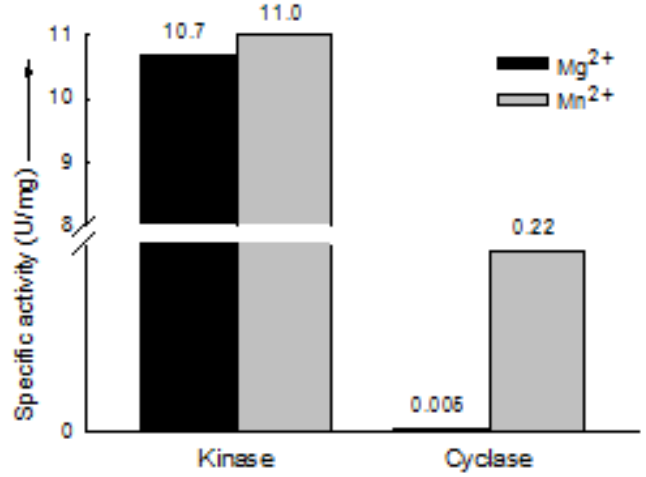

Figure 1. Specific activities $(\mathrm{U} / \mathrm{mg})$ for the natural and promiscuous reactions catalysed by DHAK in presence of $\mathrm{Mg}^{2+}$ or $\mathrm{Mn}^{2+}$. Activities were measured at 25 ${ }^{\circ} \mathrm{C}$ with $12 \mathrm{mM}$ of $\mathrm{Me}^{2+}$. In the kinase reaction with $\mathrm{Mn}^{2+}, 1.35 \mathrm{mM}$ of $\mathrm{Me}^{2+}$ was used to avoid inhibition by manganese excess (see Figure 2 ).

A detailed analysis of the behaviour of the two activities as function of the $\mathrm{Mn}^{2+}$ concentration showed that at low concentrations, the DHAK is able to catalyse both, the phosphorylation of DHA and the cyclization of the FAD (Figure 2). However, from a concentration of $\mathrm{Mn}^{2+}$ about $1.5 \mathrm{mM}$, the kinase activity begins to be inhibited while the cyclase activity reaches the saturation without detecting inhibition by effect of $\mathrm{Mn}^{2+}$. Although, $1.5 \mathrm{mM}$ is a concentration of manganese much more higher than the intracellular concentration of $10 \mu \mathrm{M}$ usually assumed in the literature, ${ }^{[17]}$ the $\mathrm{Mn}^{2+}$ uptake systems of Enterobacteria can increase the cytoplasmic concentration of $\mathrm{Mn}^{2+}$ over at least two orders of magnitude up to 1-3 mM on a time scale as short as a minute. ${ }^{[17,18]}$ Therefore, the cytoplasmic concentration of $\mathrm{Mn}^{2+}$ could act as a real switch that turn the kinase activity off when the cyclase activity raises the maximum.

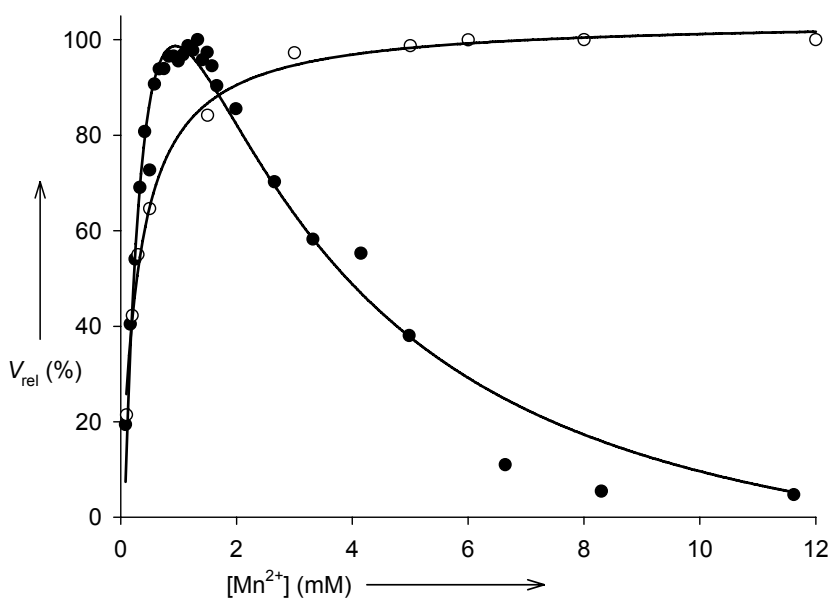

Figure 2. Natural and promiscuous activities catalysed by DHAK as function of $\mathrm{Mn}^{2+}$ concentration. $(\bullet)$ Kinase activity; (०) cyclase activity. Relative activities $\left(V_{\text {rel }}\right)$ are represented for an easier comparison.

It seems to be logical to assume that the promiscuous activities may occur in the ATP binding site of DHAK, owing to the structural similarities between ATP and FAD. To corroborate this hypothesis, we performed a series of inhibition and docking studies (see the Supporting Information). 
The results summarized in Table 2 , shown that FAD and ATP are competing by the same binding site since ATP is a strong competitive inhibitor of the cyclase activity, meanwhile DHA is a poor uncompetitive inhibitor. Furthermore, AMP, which moiety is shared by both ATP and FAD, it is a competitive inhibitor of both activities.

\begin{tabular}{|c|c|c|c|c|}
\hline \multirow[b]{2}{*}{ Activity/substrate } & \multicolumn{4}{|c|}{$\begin{array}{c}\text { Inhibitor } \\
\text { Type of inhibition }{ }^{[a]}\left(k_{\mathrm{i}} \mathrm{mM}\right)\end{array}$} \\
\hline & DHA & ATP & FAD & AMP \\
\hline Kinase/Mg-ATP & N.I & - & - & $\begin{array}{l}\text { C.I } \\
(10.2)\end{array}$ \\
\hline Kinase/Mn-ATP & N.I & - & $\begin{array}{c}\text { M.I } \\
\left(k_{\mathrm{ic}}=0.5\right) \\
\left(k_{\mathrm{iu}}=3.0\right)\end{array}$ & $\begin{array}{c}\text { C.I } \\
(71.8)\end{array}$ \\
\hline Cyclase/Mn-FAD & $\begin{array}{c}\text { U.I } \\
(576)\end{array}$ & $\begin{array}{c}\text { C.I } \\
\left(0.2 \times 10^{-3}\right)\end{array}$ & - & $\begin{array}{c}\text { C.I } \\
(3.52)\end{array}$ \\
\hline
\end{tabular}

[a] C.I=competitive inhibition; U.I=uncompetitive inhibition; M.I=mixed inhibition; N.I=no inhibition.

On the other hand, the behaviour of the FAD as inhibitor was more complex since it showed a mixed inhibition pattern which competitive component was higher than the uncompetitive one (Figure 3).
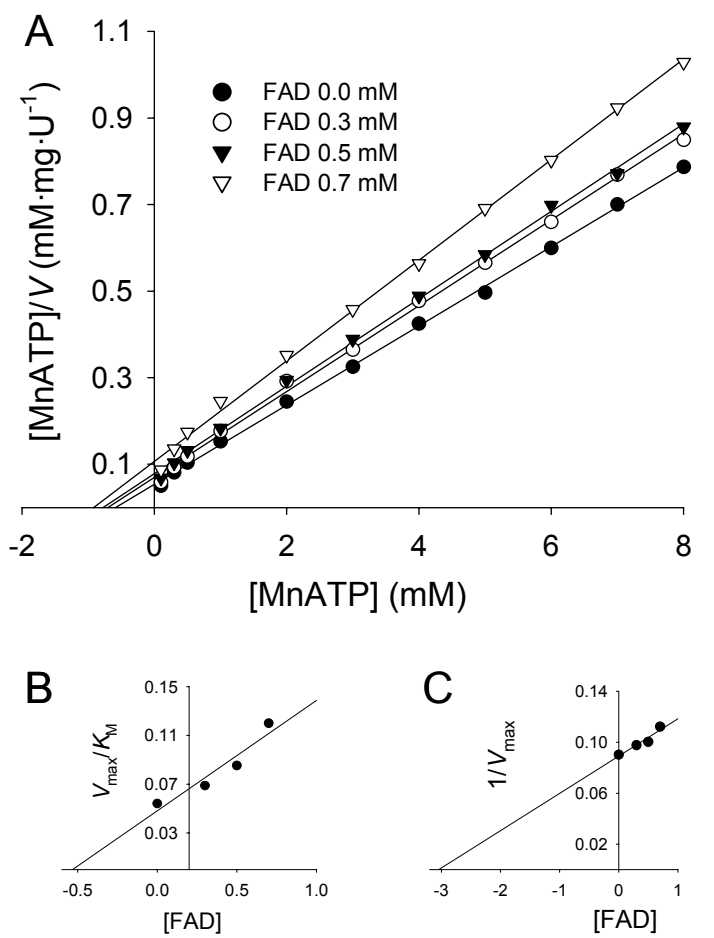

Figure 3. (A) Hanes-Woolf plot from DHAK kinetics in presence of several FAD concentrations. (B) and (C) are secondary plots used to calculate $k_{\text {iu }}$ and $k_{\text {ic }}$.

This behaviour could be explained if $F A D$ is bound to the active centre in two sub-sites, one of them coincident with the ATP binding site and the other probably related with the bound of the isoalloxazine ring of the FAD. This interpretation was supported by docking studies.
Scheme 3 shown the minimized FAD bound in the ATP binding site of the DHAK from C. freundii strain DSM 30040 (pdb 1un9). ${ }^{11}$ The phosphate groups of FAD are positioned where the ATP ones in the crystal structure which are coordinated by two $\mathrm{Mg}^{2+}$ with the $\gamma$-carboxyl groups of aspartyl residues (Asp380, Asp385 and Asp387). Asp385 is at hydrogen bond distance (3.0 $\AA$ ) of the $-\mathrm{OH} 5$ involved in the cyclization of FAD. ${ }^{16 \mathrm{~b}}$ Besides these residues, Val434 and Gly113, that do not participate in the binding of ATP, could be interacting with the isoalloxazine ring of the FAD.

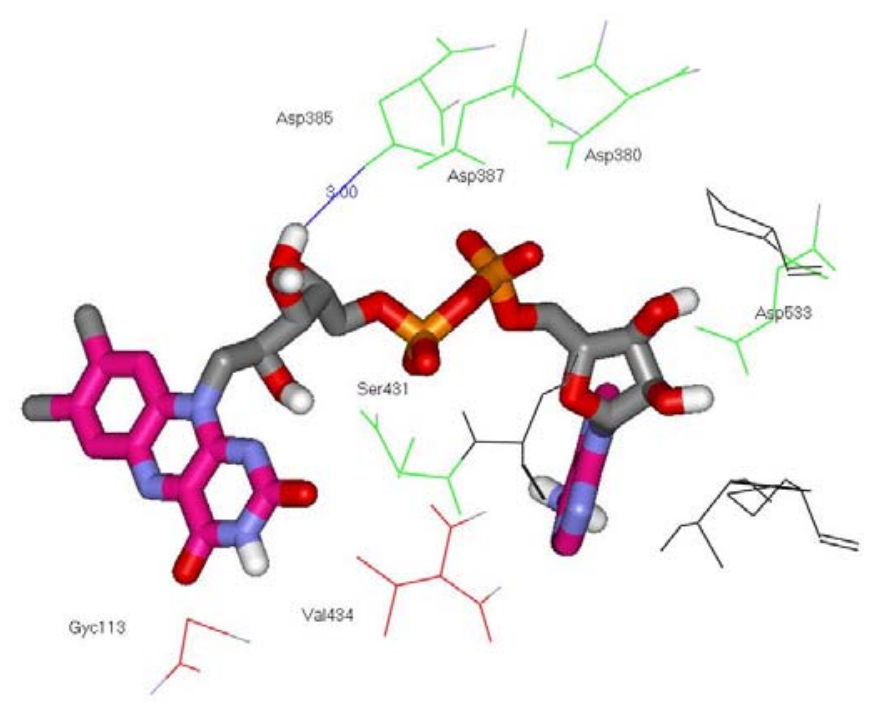

Scheme 3. FAD docked into the ATP binding site of DHAK enzyme (stick) from C. freundii strain DSM 30040 (pdb 1un9). ${ }^{11}$ In green are represented the aa that interact with both ATP and FAD; in black those that only interact with ATP and in red those residues that interact only with the FAD.

Interestingly, the kinetic parameters of the FMN cyclase activity determined for the DHAK from C. freundii CECT 4626 are quite different from those reported by Cameselle and co-workers for the rat liver enzyme. ${ }^{16 \mathrm{~b}}$ The results summarized in Table 3 clearly shown that the rat liver enzyme is much more efficient as cyclase that the bacterial enzyme. Thus, the $k_{\text {cat }} / K_{\mathrm{M}}$ value of the rat enzyme is more than one order of magnitude higher than the value of the $C$. freundii enzyme.

$\begin{aligned} & \text { Table 3. Kinetic parameters of } 4^{\prime}, 5^{\prime} \text {-cFMN cyclase from C. freundii CECT } 4626 \\ & \text { and rat liver. }\end{aligned}$
$\begin{array}{lllll}\text { DHAK source } & \begin{array}{l}\text { Specific activity } \\ (\mathrm{U} / \mathrm{mg})\end{array} & K_{\mathrm{M}}(\mathrm{mM}) & k_{\text {cat }}\left(\mathrm{s}^{-1}\right) & k_{\text {cat }} / K_{\mathrm{M}}\left(\mathrm{s}^{-1} / \mathrm{M}\right) \\ \begin{array}{l}\text { C. freundii } \\ \text { CECT } 4626^{[\mathrm{a}]}\end{array} & 0.5 & 0.022 & 0.68 & 3.1 \times 10^{4} \\ \text { Rat liver }^{[\mathrm{b}]} & 3.2 & 0.009 & 4.82 & 5.3 \times 10^{5}\end{array}$

[a] Kinetic parameters calculated at $37^{\circ} \mathrm{C}$ for comparison purposes. [b] Data taken from reference $16 \mathrm{~b}$.

These results suggested that, in this case promiscuity is playing a role in the divergence of a novel enzyme function. Based on aminoacid sequence, the DHAK's from Citrobacter, plants and mammals grouped into the same class (Figure 4 and reference 7 ). 
Althought, the relationships between classes as shown by the branching order at the centre of this unrooted tree is unreliable, evolutionary information can be derived within each class. Therefore, our results suggest that enzymes in this separate branch has been under a process of divergent molecular evolution, along which the promiscuous function acquired higher activity and specificity.

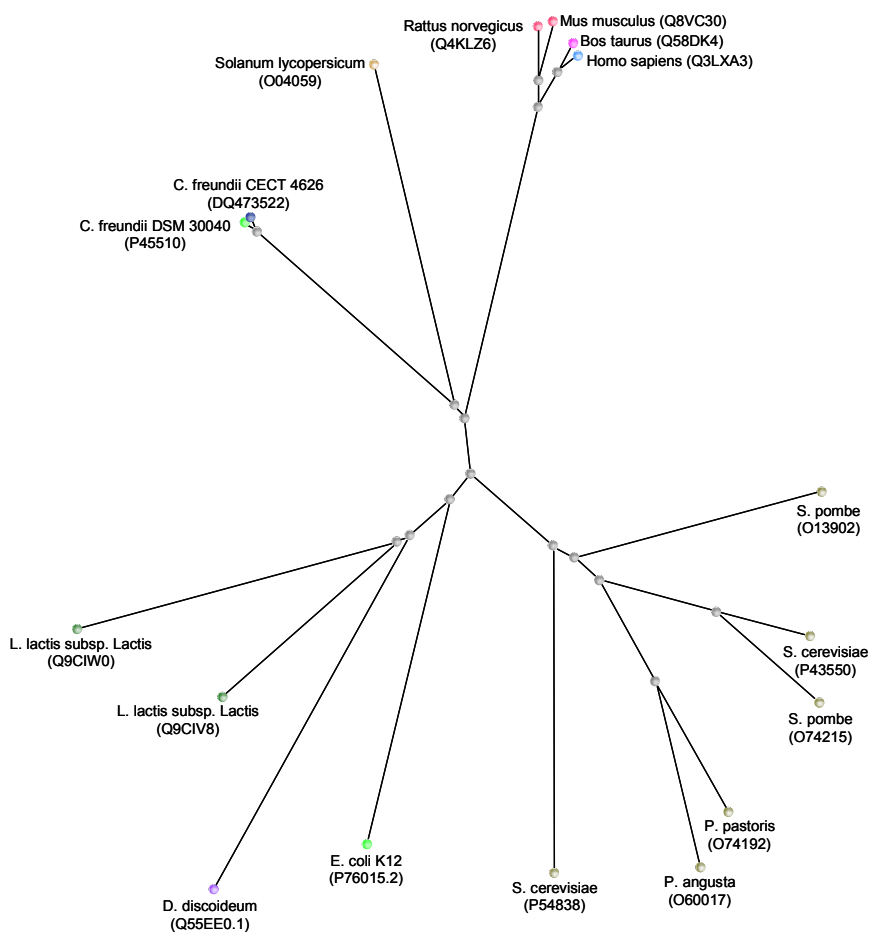

Figure 4. Unrooted tree showing the sequence relationships between DHAK from C. freundii CECT 4626 and DHAK-like proteins in the Swiss-Prot database (for details see the Supporting Information).

In conclusion, we have described the natural promiscuous behaviour of the DHAK from Citrobacter freundii CECT 4626. This catalytic promiscuity is modulated by the divalent cation that forms the complex with the phosphorylated substrate. Through kinetic and docking studies we have demonstrated that both activities are linked to the same binding site. The present results shown that the DHAK plasticity is involved in the adquisition of a new catalytic function according to the model proposed by Tawfik and others. ${ }^{[2,3]}$

\section{Acknowledgements}

This work was supported by grants from Ministerio de Educación y Ciencia (CTQ2004-03523/BQU and CTQ2007-67403/BQU). I. S. $-M$ and $L$. I were supported by a predoctoral fellowship from Comunidad de Madrid.

Keywords: biotransformations - catalytic promiscuity · cofactors $\cdot$ enzyme evolution $\cdot$ metalloenzymes
[1] For some recent reviews on Enzyme Promiscuity see: a) K. Hult, P. Berglund, Trends Biotechnol. 2007, 25, 231-238; b) R. J. Kazlauskas. Curr. Opin. Chem. Biol. 2005, 9, 195-201; c) U. T. Bornscheuer, R. J. Kazlauskas, Angew. Chem. 2004, 116, 6156-6165; Angew. Chem. Int. Ed. 2004, 43, 6032-6040; d) S. D. Copley, Curr. Opin. Chem. Biol. 2003, 7, 265-272.

[2] a) O. Khersonsky, C. Roodveldt, D. S Tawfik, Curr. Opin. Chem. Biol. 2006, 10, 498-508; b) L. C. James, D. S. Tawfik, Trends Biochem. Sci. 2003, 28, 361-368; c) P. J. O’Brien, D. Herschlag, Chem. Biol. 1999, 6, R91-R105; d) R. A. Jensen, Annu. Rev. Microbiol. 1976, 30, 409-425.

[3] A. Aharoni, L. Gaidukov, O. Khersonsky, S. McQ Gould, C, Roodveldt, D. S. Tawfik, Nat. Genet. 2005, 37, 73-76.

[4] 'Evolvability' or evolutionary adaptability is defined by Tawfik et al. ${ }^{[3]}$ as the capacity of biological systems to evolve. For a discussion on this concept see: M. Kirschner, J. Gerhart, Proc. Natl. Acad. Sci. USA 1998, 95, 8420-8427.

[5] Y. Yoshikuni, T. E. Ferrin, J. D. Keasling, Nature 2006, 440, 1078-1082.

[6] a) R. N. Armstrong, Biochemistry, 2000, 45, 13625-13632; b) F. van de Velde, L. Könemann, F. van Rantwijk, R. A. Sheldon Biotechnol. Bioeng. 2000, 67, 87-96; c) D. Qi, C. M. Tann, D. Haring, M. D. Distefano, Chem. Rev. 2001, 101, 3081-3112; d) N. Tanaka, V. Dumay, Q. Liao, A. J. Lange, R. Wever, Eur. J. Biochem, 2002, 269, 2162-2167; e) A. Fernández-Gacio, A. Codina, J. Fastrez, O. Riant, P. Soumillion, ChemBioChem 2006, 7, 1013-1016; f) K. Okrasa R. J. Kaslauskas, Chem. Eur. J. 2006, 12, 1588-1596.

[7] For a review on the function, structure and phylogeny of dihydroxyacetone kinases see: B. Erni, C. Siebold, S. Christen, A Srinivas, A. Oberholzer, U, Baumann, Cell Mol. Life Sci. 2006, 63, 890900.

[8] The strain DSM 30040 used in these works is now listed in the German Collection of Microorganisms and Cell Cultures (DSMZ) catalogue under the specie Citrobacter braakii (http://www.dsmz.de/microorganisms/ html/strains/strain.dsm030040.html).

[9] a) R. Daniel, G. Gottschalk, FEMS Microbiol. Lett. 1992, 100, 281-286; b) R. Daniel, K. Stuerzt, G. Gottschalk, J. Bacteriol. 1995, 177, 43924401.

[10] L. F. García-Alles, C. Siebold, T. N. Nyffeler, K. Flükiger-Brühwiler, P Schneider, H.-B. Bürgi, U. Baumann, B. Erni, Biochemistry 2004, 43, 13037-13045.

[11] C. Siebold, I. Arnold, L. F. García-Alles, U. Baumann, B. Erni, J. Biol. Chem. 2003, 278, 48236-48244.

[12] S. Cheek, K. Ginalski, H. Zhang, N. V. Grishin, BMC Struct. Biol. 2005, 5, 6.

[13] N. Itoh, Y. Tujibata, J. Q. Liu, Appl. Microbiol. Biotechnol. 1999, 51, 193200.

[14] I. Sánchez-Moreno, J. F. García-García, A. Bastida, E. García-Junceda, Chem. Commun. 2004, 1634-1635.

[15] A Cabezas, M. J. Costas, R. M. Pinto, A. Couto, J. C. Cameselle, Biochem. Biophys. Res. Commun. 2005, 338, 1682-1689.

[16] a) F. J. Fraiz, R. M. Pinto, M. J. Costas, M. Ávalos, J. Canales, A. Cabezas, J. C. Cameselle, Biochem. J. 1998, 330, 881-888; b) A. Cabezas, R. M. Pinto, F. J. Fraiz, J. Canales, S. González-Santiago, J. C Cameselle, Biochemistry 2001, 40, 13710-13722.

[17] D. G. Kehres, M. E. Maguire, FEMS Microbiol. Rev. 2003, 27, 263-290.

[18] D. G.Kehres, A. Janakiraman, J. M. Slauch, M. E. Maguire, J. Bacteriol. 2002, 184, 3159-3166.

Received: ((will be filled in by the editorial staff))

Published online: ((will be filled in by the editorial staff)) 
Entry for the Table of Contents (Please choose one layout)

Layout 1:

\section{COMMUNICATIONS}

In this communication we describe the promiscuous behaviour of the dihydroxyacetone (DHA) kinase from Citrobacter freundii strain CECT 4626. This ATP-dependent DHAK is able to catalyse, beside the transfer of the $\gamma$ phosphate of the ATP to DHA, the cyclization of the FAD to yield riboflavin 4',5'-cyclic phosphate $\left(4^{\prime}, 5\right.$ 'cFMN). This catalytic promiscuity is modulated by the divalent cation that forms the complex with the phosphorylated substrate.

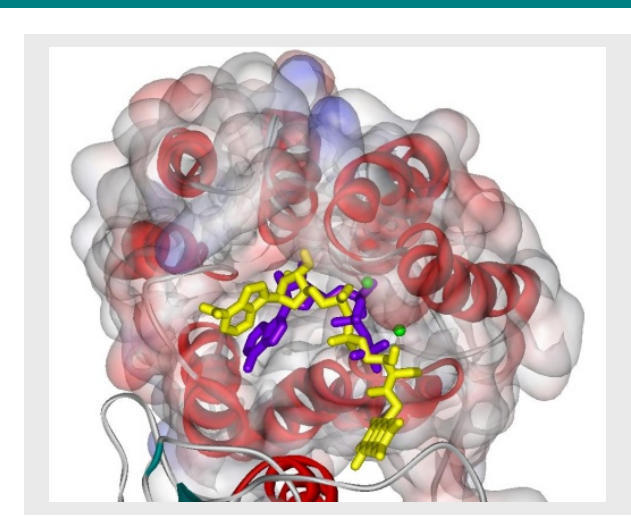

Israel Sánchez-Moreno, Laura Iturrate, Rocio Martín-Hoyos, María Luisa Jimeno, Montaña Mena, Agatha Bastida and Eduardo García-Junceda*

Page No. - Page No.

From kinase to cyclase: an unusual example of catalytic promiscuity modulated by metal switching 
From kinase to cyclase: an unusual example of catalytic promiscuity modulated by metal switching.

Israel Sánchez-Moreno, Laura Iturrate, Rocío Martín-Hoyos, María Luisa Jimeno, Montaña Mena, Agatha Bastida and Eduardo García-Junceda*

\section{Supporting Information}

\section{Contents}

Materials and General Procedures.

page S2

Cloning, overexpression and purification of DHAK.

page S2

Protein analysis.

page $\mathrm{S} 3$

Enzyme activity assays.

page S3

Steady-state kinetic assays and inhibition studies

page S5

NMR procedures.

page S6

NMR structural elucidation.

page S7

Molecular docking studies.

page $\mathrm{S} 10$

Sequence similarity searching and phylogenetic tree analysis.

page $\mathrm{S} 11$ 
Materials and General Procedures

SDS-PAGE was performed using $10 \%$ and $5 \%$ acrylamide in the resolving and stacking gels, respectively. Gels were stained with Coomassie brilliant blue R-250 (Applichem GmBH, Germany). Electrophoresis were always run under reducing conditions, in the presence of 5\% $\beta$ mercaptoethanol. Protein and DNA gels were quantified by densitometry. Triosephosphate isomerase (TIM) and $\alpha$-glycerophosphate dehydrogenase $(\alpha \mathrm{GDH})$, were purchased from SigmaAldrich (St. Louis, MO). Restriction enzymes, Taq polymerase and T4-DNA ligase were purchased from MBI Fermentas AB (Lithuania). Citrobacter freundii CECT 4626 was provided from the Spanish Type Culture Collection (CECT). E. coli BL21(DE3) competent cells were purchased from Stratagene Co. (San Diego, CA). PCR primers were purchased from Isogen Life Science (Spain) and the pRSET-A expression vector was purchased from Invitrogen Co. (Carlsbad, CA). Isopropyl$\beta$-d-thiogalactopyranoside (IPTG) was purchased from Applichem GmBH (Germany). Plasmids and PCR purification kits were from Promega (Madison, WI) and DNA purification kit from agarose gels was from Eppendorf (Hamburg, Germany). Nickel-iminodiacetic acid ( $\mathrm{Ni}^{2+}$-IDA) agarose was supplied by Agarose Bead Technologies (Spain). All other chemicals were purchased from commercial sources as reagent grade.

\section{Cloning, overexpression and purification of DHAK from C. freundii CECT 4626}

DNA manipulation was according to standard procedures (Sambrook et al. 1989). DNA template for amplification of the dhak gene was obtained from the Citrobacter freundii strain CECT 4626. Primers for PCR amplification were designed based on the nucleotide sequence of the dhak gene from the strain DSM 30040 (GeneBank Accession No U09771). The oligonucleotides 5'ATATTAAGCTTCAAAACATTACTCAG-3' and 5'TATTACTCGAGTTACAGCCAGCGCACTGGC-3' were used as leftward and rightward primers respectively (the recognition sequence for HindIII and XhoI are underlined). PCR amplification was performed in a $100 \mu \mathrm{l}$ reaction mixture and subjected to 30 cycles of amplification. The cycle conditions were set as follows: denaturation at $94^{\circ} \mathrm{C}$ for $1 \mathrm{~min}$, annealing at $55{ }^{\circ} \mathrm{C}$ for $1 \mathrm{~min}$ and elongation at $72{ }^{\circ} \mathrm{C}$ for $1.5 \mathrm{~min}$. The purified PCR product was digested with XhoI and HindIII and ligated into the doubled digested vector pRSET-A to yield the plasmid pRSET-dhak. This plasmid was transformed into E. coli BL21(DE3) competent cells.

A colony containing the plasmid pRSET-dhak was cultured in Luria-Bertani (LB) broth containing ampicillin $(250 \mu \mathrm{g} / \mathrm{ml})$ at $37^{\circ} \mathrm{C}$ with shaking. When the culture reached an $\mathrm{O}^{\circ} \mathrm{D}_{600 \mathrm{~nm}}$ of $0.5-0.6$, DHAK expression was induced with IPTG $(1 \mathrm{mM})$ and the temperature was dropped to $30{ }^{\circ} \mathrm{C}$. The culture was maintained $\mathrm{O} / \mathrm{N}$. After that, the culture was centrifuged at $10,000 \mathrm{x} \mathrm{g}$ during $10 \mathrm{~min}$ at 4 ${ }^{\circ} \mathrm{C}$ and the resulting pellet was treated with lysozyme and DNase for protein extraction. ${ }^{1}$

The recombinant protein containing an $\mathrm{N}$-terminal $6 x \mathrm{His}$ tag was purified in a $\mathrm{Ni}^{+2}$-IDA-agarose column pre-equilibrated with sodium phosphate buffer $(20 \mathrm{mM}, \mathrm{pH} 7.5)$. DHAK was eluted with the same buffer containing imidazole $0.25 \mathrm{M}$. All the fractions containing protein were pooled together and further purified by size-exclusion chromatography on a HiLoad 26/60 Superdex 75 PG column controlled using the AKTA-FPLC system (GE Healthcare Life Science). The column was developed in $50 \mathrm{mM}$ phosphate buffer $\mathrm{pH} 7.2$ containing $\mathrm{NaCl}(0.15 \mathrm{M})$ at a constant flow rate of $1.0 \mathrm{ml} / \mathrm{min}$ (SFigure 1).

\footnotetext{
${ }_{1}^{1}$ A. Bastida, A. Fernández-Mayoralas, R. Gómez, F. Iradier, J. C. Carretero, E. García-Junceda, Chem. Eur. J. 2001, 7, 2390-2397
} 


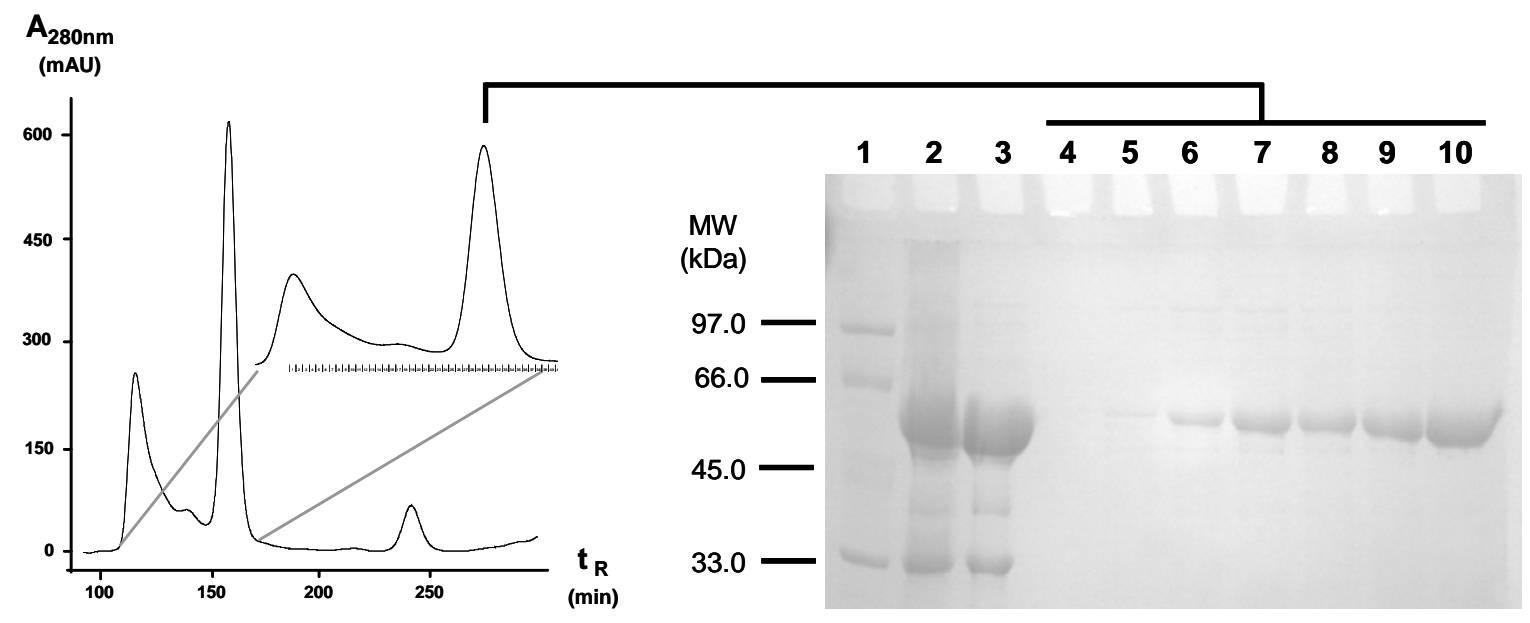

SFigure 1. Purification of the recombinant DHAK. Chromatogram of the size-exclusion step. SDS-PAGE shows: lane 1, low molecular weight markers; lane 2, cell free extract; lane 3, DHAK after IMAC step; lanes 4-10 fractions containing DHAK activity.

\section{Protein analysis}

Amino acid analysis of purified DHAK aliquots was performed at the Department of Biochemistry and Molecular Biology of the Complutense University of Madrid to determine the protein concentration. The absorption spectrum of different quantified samples allowed determination of the molar extinction coefficient of DHAK at $280 \mathrm{~nm}\left(\varepsilon^{280}=44432.5 \mathrm{M}^{-1} \cdot \mathrm{cm}^{-1}\right)$.

Peptide mass fingerprint analysis from the SDS-PAGE band corresponding to the putative recombinant DHAK was performed at the Proteomic Unit of the Spanish National Center of Biotechnology (Centro Nacional de Biotecnología, CSIC). Samples were digested with sequencing grade trypsin overnight at $37^{\circ} \mathrm{C}$. The analysis by MALDI-TOF mass spectrometry produces peptide mass fingerprints and the peptides observed can be collated and represented as a list of monoisotopic molecular weights. Data were collected in the $\mathrm{m} / \mathrm{z}$ range of 800-3600. 29 peptides covering the major part of the amino acid sequence of the protein were identified (SFigure 2). Almost all the predicted tryptic peptides with molecular masses falling in the analyzed $\mathrm{m} / \mathrm{z}$ range were found in the peptide mass fingerprint of the recombinant DHAK. Peptide mass fingerprinting verified that purified protein had the expected features of DHAK from C. freundii CECT 4626.

\section{Enzyme activity assays}

Phosphorylation of DHA was measured spectrophotometrically in a coupled enzymatic assay based in the reduction of DHAP to $\alpha$-glycerophosphate, catalyzed by $\alpha \mathrm{GDH}$ with concomitant oxidation of NADH to $\mathrm{NAD}^{+}$. The assays were run at 25 or $37^{\circ} \mathrm{C}$ following the decrease of absorbance at 340 $\mathrm{nm}\left(\varepsilon_{N A D H}^{340}=6220 \mathrm{~cm}^{-1} \cdot \mathrm{M}^{-1}\right)$ for 10 minutes in reaction mixtures of $1 \mathrm{ml}$ containing Tris- $\mathrm{HCl}(40$ $\mathrm{mM}, \mathrm{pH} 8.0)$, DHA $(2.5 \mu \mathrm{mol}), \mathrm{NADH}(0.2 \mu \mathrm{mol}), \operatorname{ATP}(5.0 \mu \mathrm{mol}), \mathrm{MgSO}_{4}(5.0 \mu \mathrm{mol}), \alpha \mathrm{GDH}$ (1.26 U), TIM (12.6 U) and DHAK. One unit of kinase activity was defined as the amount that produces $1 \mu \mathrm{mol}$ of DHAP per min under the above conditions. 


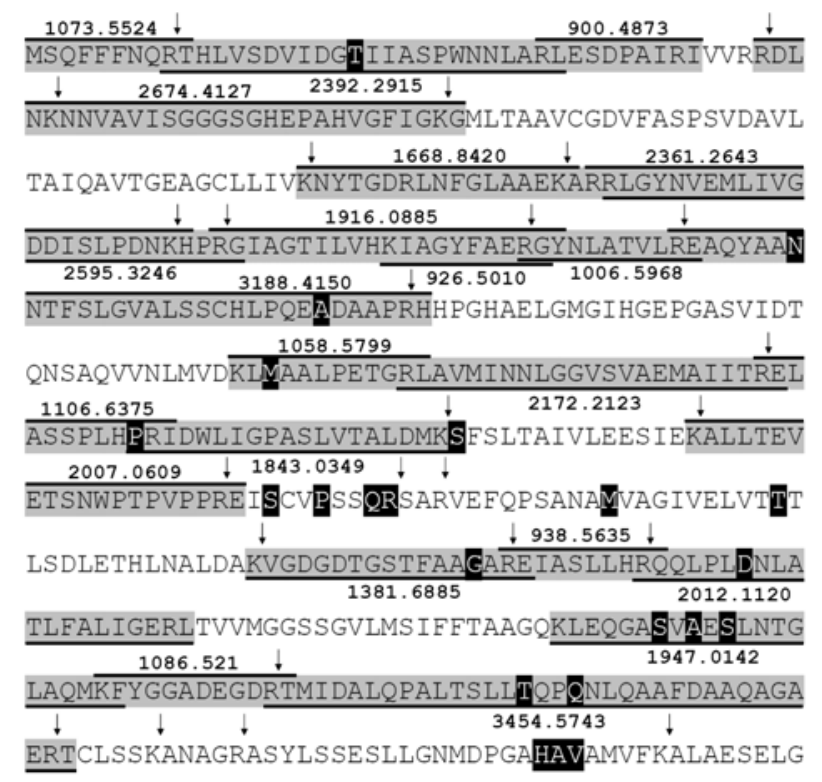

SFigure 2. Peptide mass fingerprint of DHAK from C. freundii CECT 4626. Sequence of DHAK, indicating the theoretical trypsin cleavage sites $(\downarrow)$. The sequence of the identified peptides are shaded and underlined when overlapping. Molecular mass of each peptide is indicated in Da. Bold-inverted cells indicate the modified aminoacid with respect to the sequence of the protein from the strain DSM 30040.

FMN cyclase activity was determined by measuring the formation of 4',5'-cFMN from FAD by HPLC with $\mathrm{A}_{430 \mathrm{~nm}}$ monitoring in reaction mixtures of $1 \mathrm{ml}$ containing Tris- $\mathrm{HCl}(40 \mathrm{mM}, \mathrm{pH} 7.5)$, $\mathrm{MnCl}_{2}(12 \mathrm{mM}), \mathrm{FAD}(0.25 \mathrm{mM})$ and DHAK. Full reaction mixtures were incubated from 10 to 60 min. HPLC was performed in an Inertsil ODS-2 column following the previously described assay with minor modifications. ${ }^{2}$ The mobile phase employed was $20 \mathrm{mM}$ sodium phosphate, $\mathrm{pH} 6.0$, and methanol at a final concentration of $35 \%(\mathrm{v} / \mathrm{v})$ and the chromatography was run under isocratic conditions at $1 \mathrm{ml} / \mathrm{min}$ flow rate (SFigure 3). One unit of cyclase activity was defined as the amount of enzyme that produces $1 \mu \mathrm{mol}$ of 4',5'-cFMN per min under the above conditions.

\section{FAD}

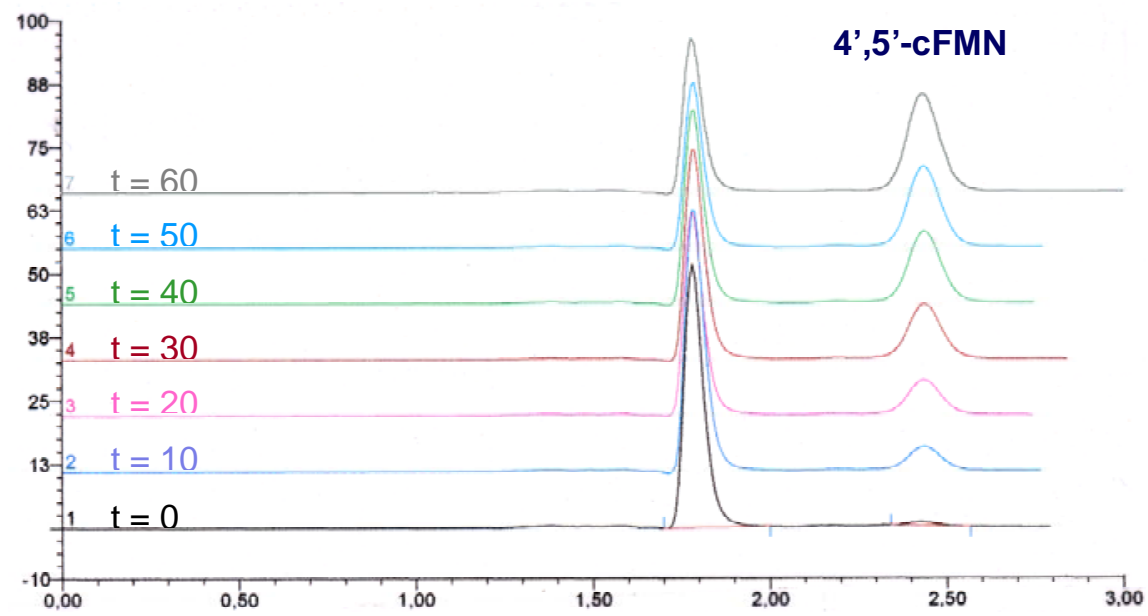

SFigure 3. HPLC chromatograms of the cyclization reaction catalysed by the DHAK from C. freundii strain CECT 4626.

${ }^{2}$ F. J. Fraiz, R. M. Pinto, M. J. Costas, M. Ávalos, J. Canales, A. Cabezas, J. C. Cameselle, Biochem. J. 1998, 330: 881888. 
Steady-state kinetic assays and inhibition studies

Steady-state kinetic assays for kinase activity were measured at $25{ }^{\circ} \mathrm{C}$ in 96 -well plates in a total volume of $0.3 \mathrm{ml}$. Measurements of kinetic parameters for DHA were performed with $0.08 \mu \mathrm{g} / \mathrm{ml}$ of purified DHAK at ten different DHA concentrations and with saturating concentration of $[\mathrm{MgATP}]^{2-}(5.0 \mathrm{mM})$ (SFigure $\left.5 \mathrm{~A}\right)$. Assays to determine the kinetic parameters for $[\mathrm{MgATP}]^{2-}$ complex were performed with $1.0 \mu \mathrm{g} / \mathrm{ml}$ of purified DHAK at sixteen concentrations of complex using a constants $\mathrm{Mg}^{2+}$ excess of $40 \mathrm{mM}$ and $2.5 \mathrm{mM}$ of DHA (SFigure 5C). Assays to determine the kinetic parameters for [MnATP] were performed with $0.9 \mu \mathrm{g} / \mathrm{ml}$ of purified DHAK at twelve concentrations of complex using $2.5 \mathrm{mM}$ of DHA (SFigure 5D). In order to avoid $\mathrm{Mn}^{2+}$ excess inhibition (see Figure 2) the maximum $\mathrm{MnCl}_{2}$ concentration used was $1.3 \mathrm{mM}$ (7.5 fold lower than ATP concentrations in each kinetic point). Cyclase activity was measured at seven FAD concentrations in presence of $\mathrm{MnCl}_{2}(12 \mathrm{mM})$ using $4.1 \mu \mathrm{g} / \mathrm{ml}$ of purified $\mathrm{DHAK}$ in $25^{\circ} \mathrm{C}$ kinetic (SFigure 5B) and $1.7 \mu \mathrm{g} / \mathrm{ml}$ of enzyme in $37^{\circ} \mathrm{C}$ kinetic.
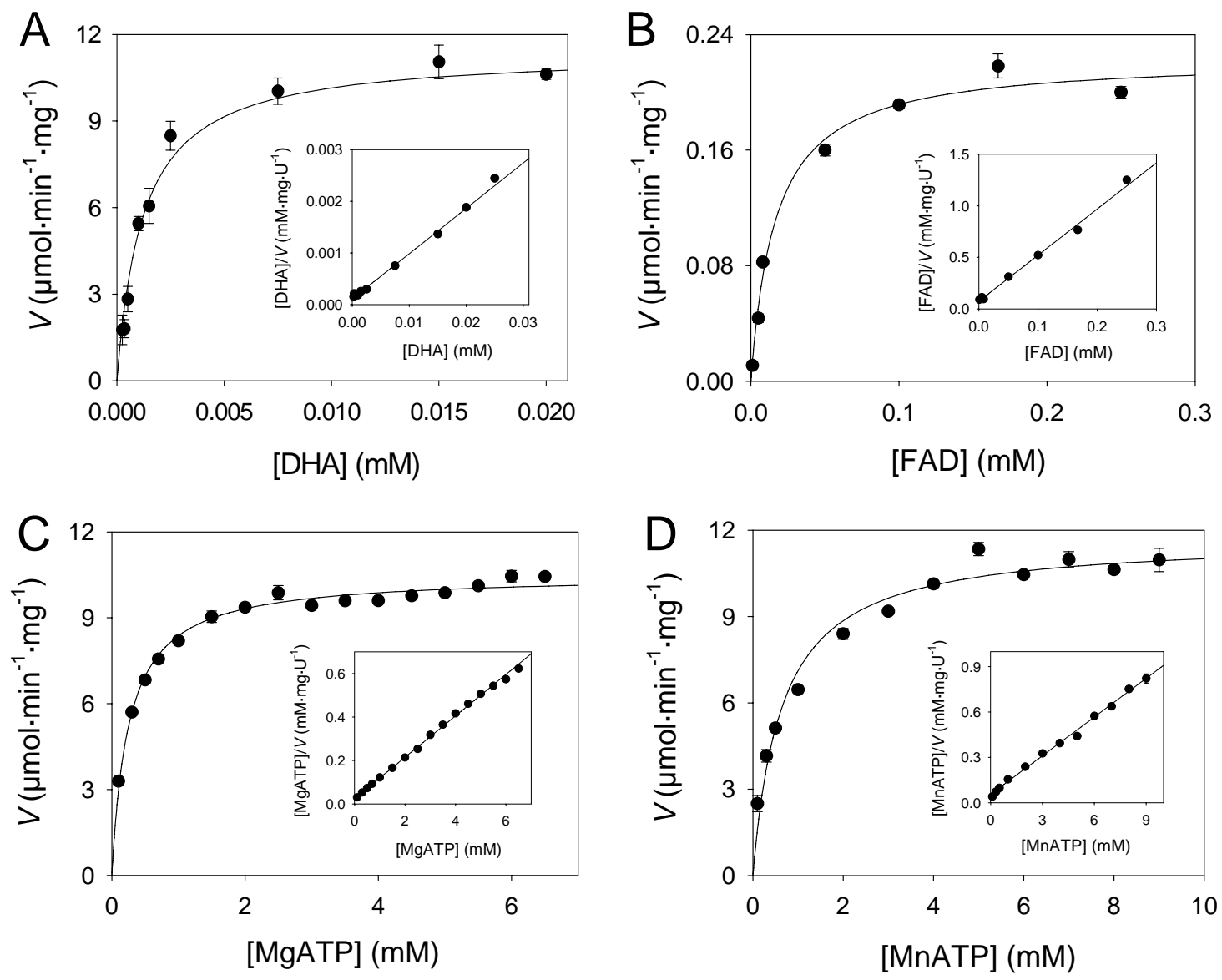

SFigure 5. Substrate kinetics of kinase an cyclase activity for DHAK from C. freundii CECT 4626 at $25^{\circ} \mathrm{C}$. Kinase activity of purified DHAK was measured at several concentrations of DHA (A), MgATP (C) and MnATP (D) maintaining constant excesses of $\operatorname{MgATP}(\mathrm{A})$ and DHA (C and D). Cyclase activity or purified DHAK was measured at various FAD concentrations in presence of $\mathrm{MnCl} 212 \mathrm{mM}$. The inserts shows Hanes-Woolf plots used for kinetic constants determination.

Kinetic constants were obtained using the built-in nonlinear regression tools in SigmaPlot 8.0 and by nonlinear regression to the experimental data using the SIMFIT package ${ }^{3}$ (url:

\footnotetext{
${ }^{3}$ H. G. Holzhütter, A. Colosimo, Bioinformatics 1989, 6, 23-28.
} 
http://www.simfit.man.ac.uk). For the determination of apparent kinetic constants (variation of only one substrate), initial velocities $\left(V_{\mathrm{i}}\right)$ were fitted to the Michaelis-Menten equation

Inhibition studies were conducted in steady-state kinetic assays for FAD, [MgATP $]^{2-}$ and $[\mathrm{MnATP}]$ in presence of several concentrations of considered inhibitor (SFigure 6). Inhibition of cyclase activity by ATP (SFigure 6A), DHA (SFigure 6B) and AMP (SFigure 6C) were analyzed in FAD activity assays in presence of increasing concentrations of inhibitor. Inhibition panther of kinase activity by AMP was analyzed using $[\mathrm{MgATP}]^{2-}$ (SFigure 6D) and [MnATP] (SFigure 6E) as phosphate donors. Inhibition of kinase activity by FAD was analyzed in [MnATP] kinetic with increasing concentrations of inhibitor (Figure 3).
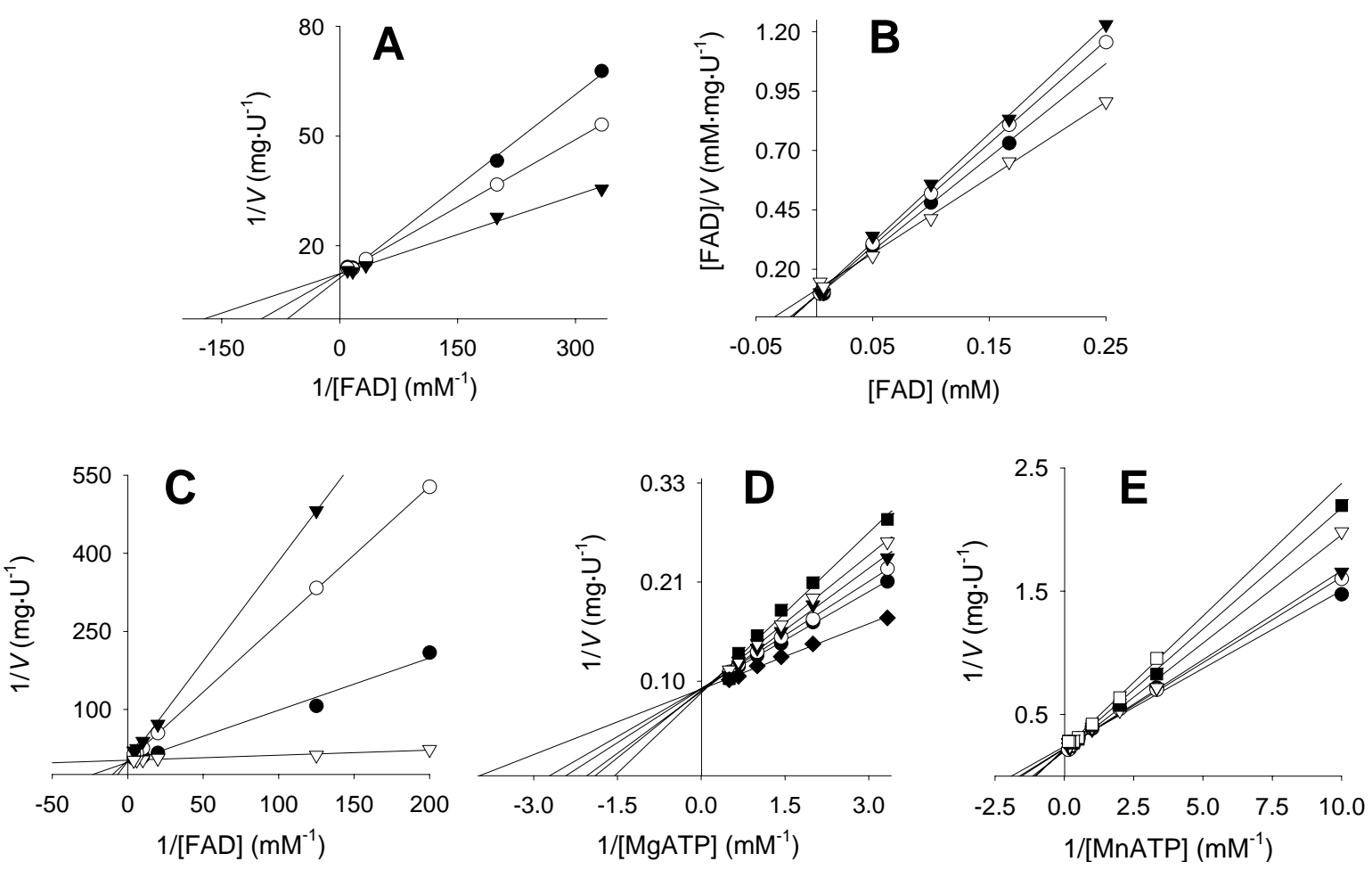

SFigure 6. Inhibition kinetics for DHAK from C. freundii CECT 4626. (A) Lineweaver-Burk plots from cyclase activity at different concentrations of FAD in presence of increasing concentrations of ATP: $30 \mathrm{nM}(\boldsymbol{\nabla}), 100 \mathrm{nM}(\mathrm{O})$ and $150 \mathrm{nM}(\bullet)$. (B) Hanes-Woolf plots from cyclase activity at different concentrations of FAD in presence of increasing concentrations of DHA: $0 \mathrm{mM}(\nabla), 50 \mathrm{mM}(\bullet), 100 \mathrm{mM}(\circ)$ and $200 \mathrm{mM}(\boldsymbol{\nabla})$. (C) Lineweaver-Burk plots from cyclase activity at different concentrations of FAD in presence of increasing concentrations of AMP: $0 \mathrm{mM}(\nabla)$, $0.5 \mathrm{mM}(\bullet), 2.5 \mathrm{mM}(\mathrm{O})$ and $5.0 \mathrm{mM}(\boldsymbol{\nabla})$. (D) Lineweaver-Burk plots from kinase activity at different concentrations of MgATP and constant excess of DHA, in presence of increasing concentrations of AMP: $0 \mathrm{mM}(\bullet), 3 \mathrm{mM}(\bullet), 6 \mathrm{mM}$ $(\mathrm{O}), 9 \mathrm{mM}(\boldsymbol{\nabla}), 12 \mathrm{mM}(\nabla)$ and $15 \mathrm{mM}(\boldsymbol{\nabla})$. (E) Lineweaver-Burk plots from kinase activity at different concentrations of MnATP and constant excess of DHA, in presence of increasing concentrations of AMP: $5 \mathrm{mM}(\bullet), 10 \mathrm{mM}(\mathrm{\circ}), 15$ $\mathrm{mM}(\boldsymbol{\nabla}), 20 \mathrm{mM}(\nabla), 25 \mathrm{mM}(\boldsymbol{\square})$ and $30 \mathrm{mM}(\square)$.

\section{NMR procedures.}

${ }^{1} \mathrm{H}$ and ${ }^{13} \mathrm{C}$ NMR spectra, using $\mathrm{D}_{2} \mathrm{O}$ as solvent, were recorded on a Varian SYSTEM 500 spectrometer equipped with a $5 \mathrm{~mm}$ HCN cold probe with field z-gradient, operating at 500.13 and 125.76 $\mathrm{MHz}$ for ${ }^{1} \mathrm{H}$ and ${ }^{13} \mathrm{C}$, respectively. The sample temperature was maintained constant at 298 K. One-dimensional NMR experiments were performed using standard Varian pulse sequences. Two-dimensional $\left[{ }^{1} \mathrm{H},{ }^{1} \mathrm{H}\right] \mathrm{NMR}$ experiments (gCOSY and TOCSY) were carried out with the following parameters: a delay time of $1 \mathrm{~s}$, a spectral width of $3000 \mathrm{~Hz}$ in both dimensions, 4096 complex points in t 2 and 4 transients for each of 256 time increments, and linear prediction to 512. 
The data were zero-filled to $4096 \times 4096$ real points. Two-dimensional $\left[{ }^{1} \mathrm{H}_{-}{ }^{13} \mathrm{C}\right] \mathrm{NMR}$ experiments (gHSQC and gHMBC) used the same ${ }^{1} \mathrm{H}$ spectral window, a ${ }^{13} \mathrm{C}$ spectral windows of $15000 \mathrm{~Hz}, 1 \mathrm{~s}$ of relaxation delay, 1024 data points, and 256 time increments, with a linear prediction to 512 . The data were zero-filled to $4096 \times 4096$ real points. Typical numbers of transients per increment were 4 and 16 , respectively.

\section{NMR structural elucidation}

Unequivocal structural elucidation of the purified product was carried out by the combined use of $1 \mathrm{D}$ and $2 \mathrm{D}\left[{ }^{1} \mathrm{H},{ }^{1} \mathrm{H}\right]$ and $\left[{ }^{1} \mathrm{H}^{13} \mathrm{C}\right]$ NMR experiments (gCOSY, TOCSY, gHSQC and gHMBC). The ${ }^{1} \mathrm{H}$ and ${ }^{13} \mathrm{C}$ 1D NMR spectra showed chemical shifts that were consistent with a mixture of two compounds in a ratio 4:1 (SFigures 7 and 8). The major compound was identified as riboflavin 4' -5 ' phosphate (cFMN). The assignment of the 7,8-dimethylisoalloxazine moiety was based on $1 \mathrm{D}{ }^{1} \mathrm{H}$ NMR and 2D gHSQC and gHMBC. Using the C11 resonance as the starting point, the assignments of all protons and carbons of the ribityl chain were obtained easily from gCOSY, gHSQC and gHMBC experiments (SFigure 9). The presence of a measurable ${ }^{3} \mathrm{~J}\left({ }^{31} \mathrm{P},{ }^{13} \mathrm{C}\right)$ coupling constant for C3' indicated the existence of a cyclic phosphate fragment. NMR relevant data are collected in Table 1 showing a good concordance with those published for cFMN.

Table 1. ${ }^{1} \mathrm{H}$ and ${ }^{13} \mathrm{C}-\mathrm{NMR}$ relevant data $\left(\delta\right.$, ppm) in $\mathrm{D}_{2} \mathrm{O}$.

\begin{tabular}{|c|c|c|c|c|c|}
\hline \multirow[b]{2}{*}{ Position } & \multicolumn{2}{|c|}{ cFMN } & \multicolumn{3}{|c|}{ AMP } \\
\hline & $\delta^{13} \mathrm{C}$ & $\delta{ }^{1} \mathrm{H}$ & Position & $\delta^{13} \mathrm{C}$ & $\delta{ }^{1} \mathrm{H}$ \\
\hline 7,8-dimethylisoalloxazine & & & Adenine & & \\
\hline 2 & 157.8 & & 2 & & 8.00 \\
\hline 4 & 161.0 & & 4 & 148.1 & \\
\hline 6 & 130.2 & 7.46 & 5 & 119.1 & \\
\hline 7 & 139.3 & & 6 & 155.6 & \\
\hline 8 & 150.6 & & 8 & 140.9 & 8.12 \\
\hline 9 & 116.7 & 7.57 & & & \\
\hline 11 & 131.4 & & & & \\
\hline 12 & 134.2 & & & & \\
\hline 13 & 149.8 & & & & \\
\hline 14 & 133.8 & & & & \\
\hline $\mathrm{CH}_{3}(\mathrm{C} 7)$ & 18.8 & 2.22 & & & \\
\hline $\mathrm{CH}_{3}(\mathrm{C} 8)$ & 20.7 & 2.37 & & & \\
\hline Ribityl Chain & & & Ribose & & \\
\hline \multirow[t]{2}{*}{1 ' } & 47.6 & 4.58 & 1 ' & 88.2 & 5.84 \\
\hline & & 4.90 & & & \\
\hline $2^{\prime}$ & 69.3 & 4.12 & 2 & 73.7 & 4.56 \\
\hline 3, & 72.5 & 3.97 & 3, & 70.5 & 4.25 \\
\hline $4^{\prime}$ & 75.2 & 4.56 & 4, & 85.7 & 4.11 \\
\hline \multirow[t]{2}{*}{5} & 66.3 & 4.16 & 5 & 61.4 & 3.74 \\
\hline & & 4.30 & & & 3.66 \\
\hline
\end{tabular}




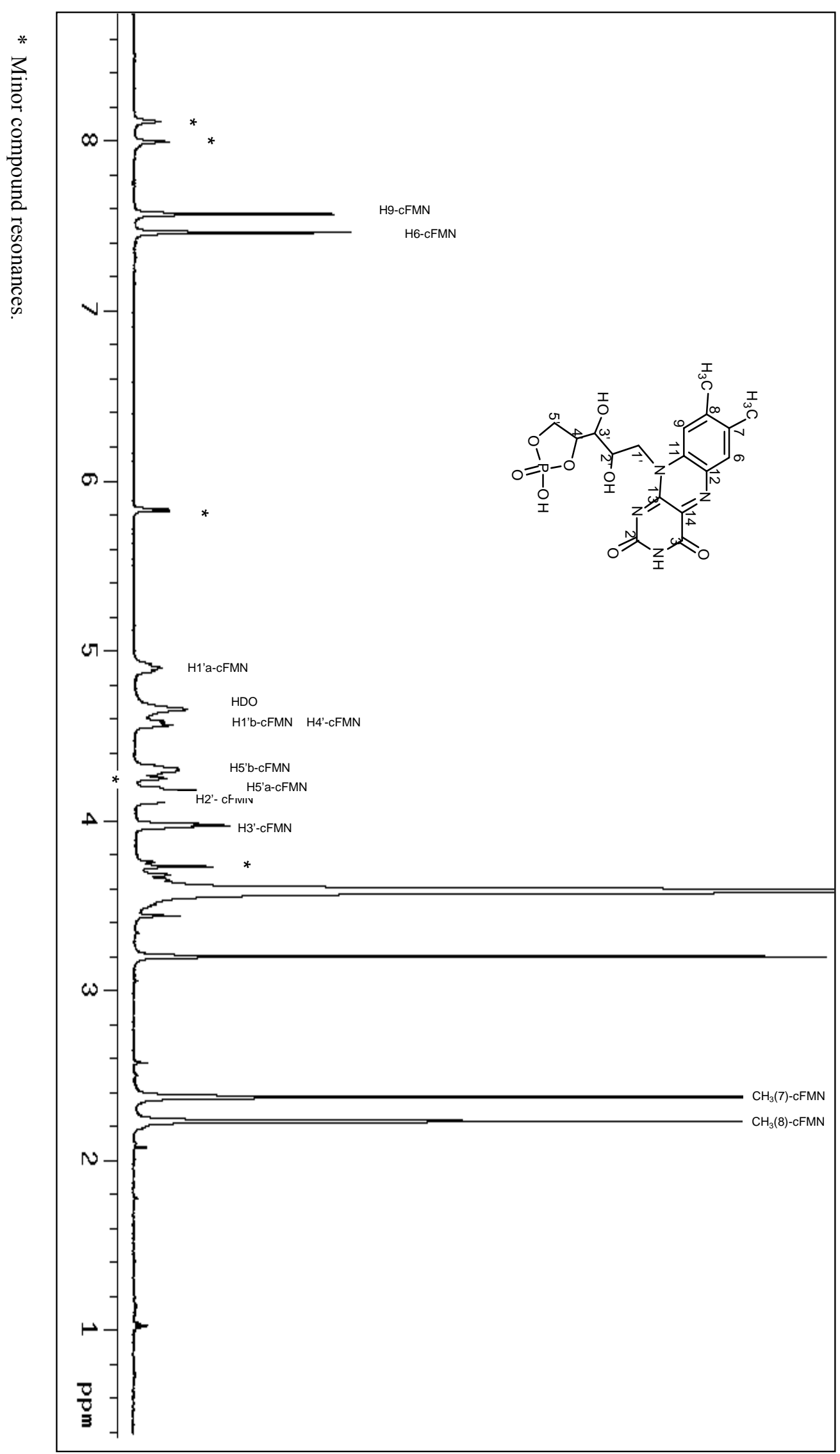

SFigure $7{ }^{1} \mathrm{H}$ NMR $\left(500 \mathrm{MHz}, \mathrm{D}_{2} \mathrm{O}\right)$ spectrum of riboflavin 4'-5' phosphate (cFMN). 


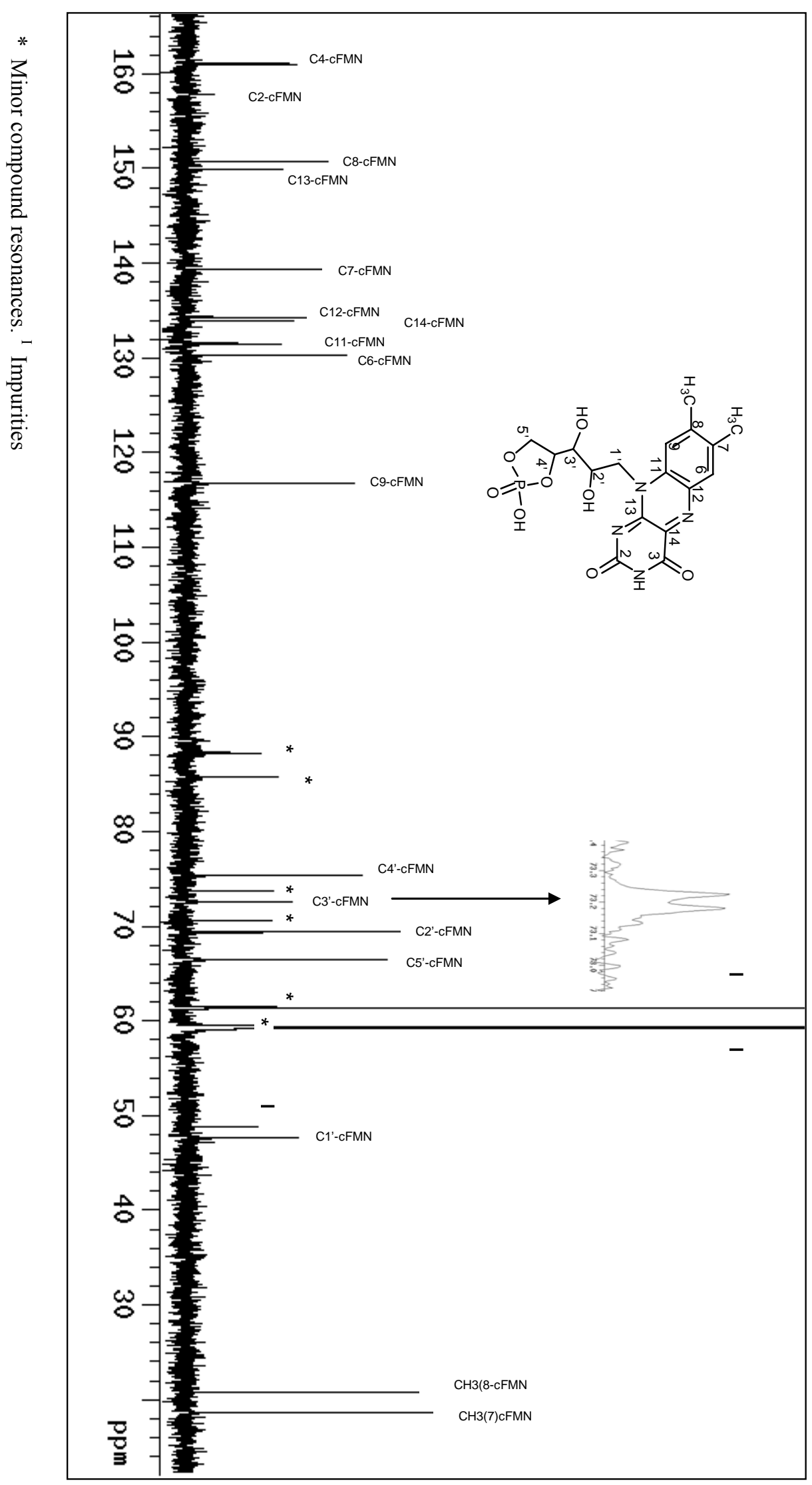

SFigure $8{ }^{13} \mathrm{C}$ NMR (125MHz, D. $\left.\mathrm{I}_{2} \mathrm{O}\right)$ spectrum of riboflavin 4'-5' phosphate (cFMN). 
Finally, the structure elucidation of the minor compound was carried out. Two aromatic singlets at 8.00 and $8.12 \mathrm{ppm}$ and an anomeric doublet at $5.84 \mathrm{ppm}$ were observed in the ${ }^{1} \mathrm{H}$ spectrum. Only sugar carbons were observed in the $1 \mathrm{D}^{13} \mathrm{C}$ spectrum. However, from gCOSY, gHSQC and gHMBC experiments (SFigure 9B) the assignment of NMR spectra was possible (Table 1). So, the minor compound was identified as adenosine 5'-phosphate (AMP).

A

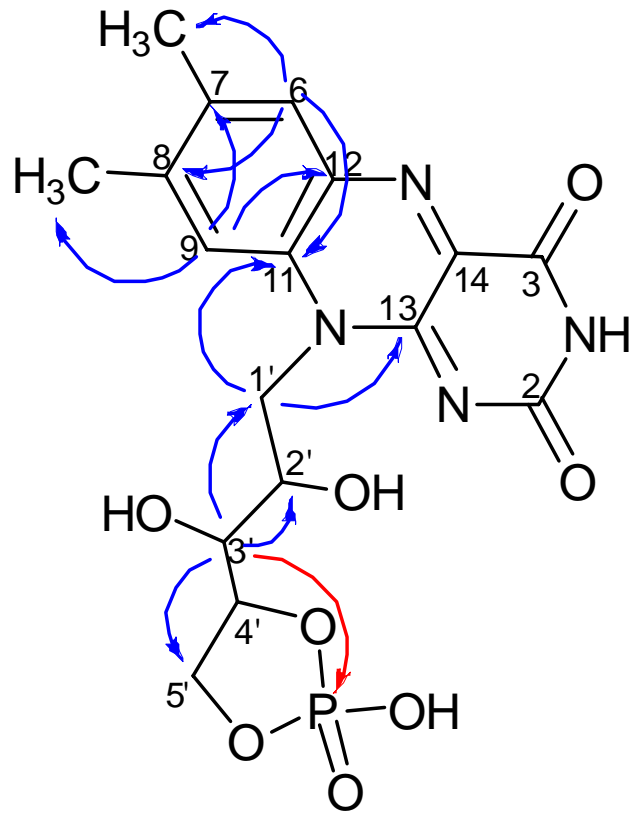

B

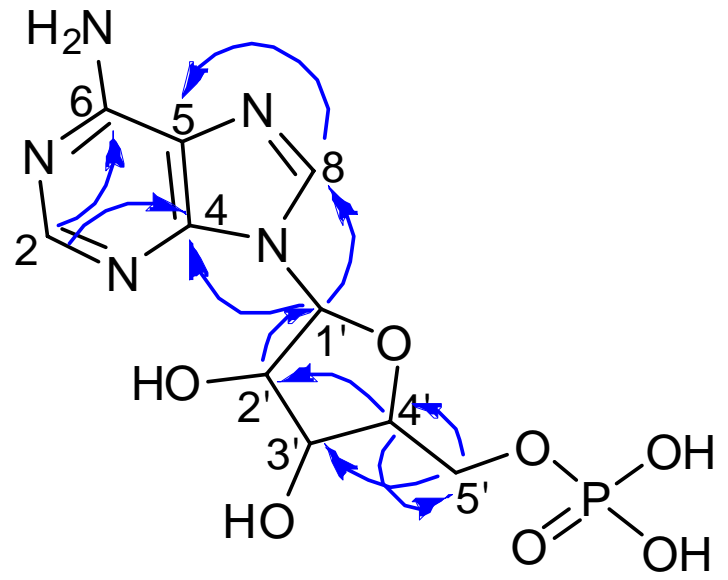

SFigure 9. Relevant observed $\left[{ }^{1} \mathrm{H}^{13} \mathrm{C}\right]$ gHMBC correlations (blue) and $\left[{ }^{1} \mathrm{H}-{ }^{31} \mathrm{P}\right] \mathrm{gHMBC}$ (red) for major and minor compounds. A: Riboflavin 4'-5' phosphate (cFMN).B: Adenosine monophosphate (AMP).

\section{Molecular docking studies}

Docking simulation was conducted with AutoDock 3.0.4 which is a fully automated docking suited of programs, which employs a genetic algorithm (GA) as a search engine. The coordinates of the protein (1un9) ${ }^{5}$ were taken from the Protein Data Bank. Before docking, compounds were minimised by Molecular mechanics (PM3) using MM3* force fields. Protein was prepared by eliminating heteroatoms and adding the hydrogen atoms (polar only). Polar hydrogen atoms and Gagsteir-Huckel were added to the compounds by using the auxiliary program AutoDock Tools (ADT). Energies were evaluated from recalculated potentials grids with molecular affinity potentials. Affinity grid files were generated using the auxiliary program Autogrid. The centers of the coordinates of the ligands were taken as the centers of the grids, and the dimensions of the grids were $76 / 63 / 123$ for the FAD with points separated by $0.37 \AA$. After docking, the 50 solutions were clustered into groups with RMS deviations of $1 \AA$. The FAD conformers were bound to the ATPbinding domain of the enzyme (L-domain; Sfigure 10). The optimal docked conformer was to the global minimum giving docked energy of $-5.38 \mathrm{Kcal} / \mathrm{mol}$

\footnotetext{
${ }^{4}$ G. M. Morris, D. S. Goodsell, R. S. Halliday, R. Huey, W. E. Hart, R. K. Belew, A. J. Olson, J. Comput. Chem. 1998, 19. 1639-1662.

${ }^{5}$ C. Siebold, I. Arnold, L. F. García-Alles, U. Baumann, B. Erni, J. Biol. Chem. 2003, 278, 48236-48244.
} 


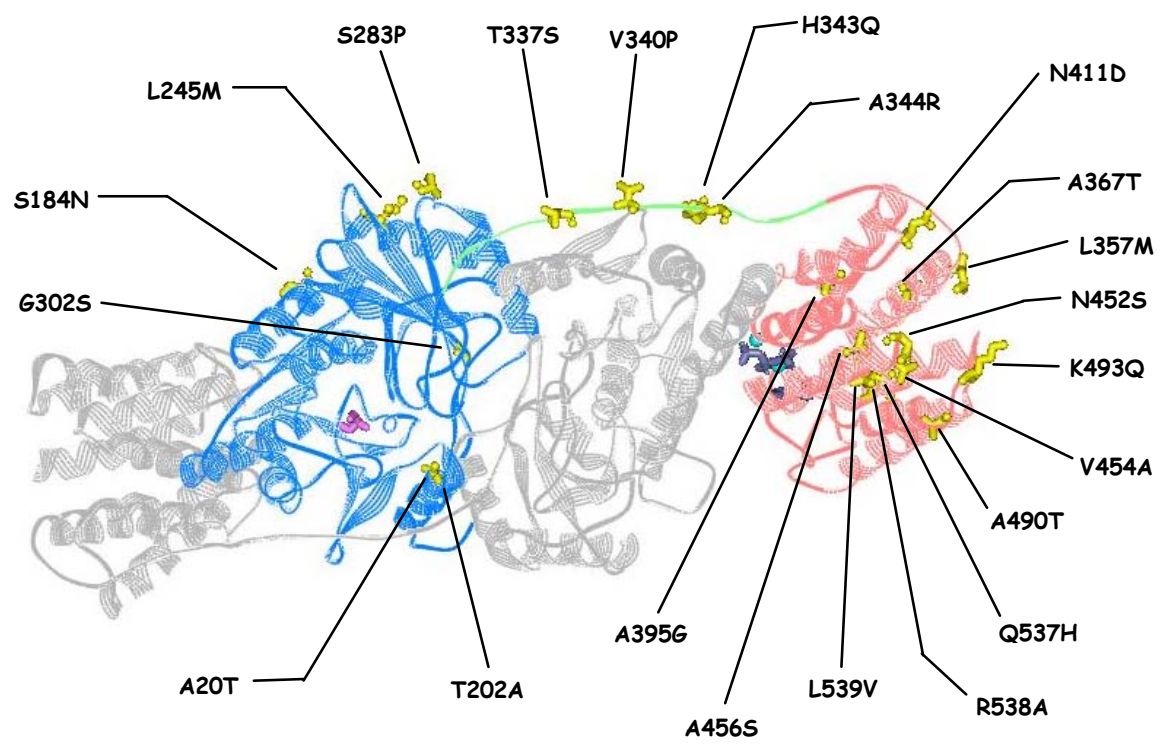

SFigure 10. 3D structure of the dimeric DHAK from C. freundii DSM 30040. ${ }^{4}$ In the N-terminal domain -K-domain (blue) - is where the DHA (purple) binding site is located. The ATP (dark blue) binding site is found in the C-terminal -L-domain (pink). In yellow are shown the amino acids in which differ the DSM 30040 isoform from the CECT 4626 isoform.

Sequence similarity searching and phylogenetic tree analysis

A similarity search for the DHAK from C. freundii CECT 4626 (GeneBank Accession $\mathrm{N}^{\mathrm{o}}$ DQ473522) was performed by BLASTP $^{6}$ on the NCBI non-redundant SwissProt database using default settings. 30 proteins sequences with significant similarity were identified and analysed by BLAST pairwise alignment. The 17 proteins showing a maximum sequence differences below 0.75 were considered to build a matrix of distance according to the Kimura method. ${ }^{7}$ Subsequently, the unrooted tree was derived by the Fast Minimum Evolution method, ${ }^{8}$ as implemented at the NCBI server.

${ }^{6}$ a) S. F. Altschul, T. L. Madden, A. A. Schäffer, J. Zhang, Z. Zhang, W. Miller, D. J. Lipman Nucleic Acids Res. 1997, 25, 3389-3402; b) S. F. Altschul, J. C. Wootton, E. M. Gertz, R. Agarwala, A. Morgulis, A. A. Schäffer, Y.-K. Yu FEBS J. 2005, 272, 5101-5109.

${ }^{7}$ M. Kimura, J. Mol. Evol. 1980, 16, 111-120.

${ }^{8}$ R. Desper, O. Gascuel, J. Comput. Biol. 2002, 9, 687-705. 